DOI

\title{
СТАТЕВІ ВІДМІННОСТІ ПОКАЗНИКІВ ПРО-АНТИОКСИДАНТНОЇ СИСТЕМИ В МІОКАРДІ ЩУРІВ ЗА УМОВ ГІПЕРГОМОЦИСТЕЇНЕМІї
}

\author{
Вінницький національний медичний університет імені М. І. Пирогова, м. Вінниця, Україна
}

РЕзЮмЕ. Гіпергомоцистеїнемія $€$ незалежним фактором ризику патології серця та судин. Одним із механізмів кардіотоксичної дії високих концентрацій гомоцистеїну $\epsilon$ оксидативний стрес. За умов гіпергомоцистеїнемії в міокарді розвивається про-антиоксидантний дисбаланс, який асоціюється з посиленням процесів вільнорадикального окиснення ліпідів та протеїнів. Однак статеві особливості впливу гіпергомоцистеїнемії на показники про-антиоксидантної системи в міокарді залишаються невивченими.

Мета дослідження - оцінити вплив гіпергомоцистеїнемії на показники оксидативного стресу в міокарді та маркери цитолізу кардіоміоцитів у самців та самок щурів.

Матеріал і методи. Досліди проведені на 40 білих лабораторних щурах обох статей масою 220-280 г. Модель гіпергомоцистеїнемії створювали шляхом введення тіолактону D, L-гомоцистеїну (Sigma, CШA) внутрішньошлунково в дозі 100 мг/кг маси протягом 28 діб. У міокарді визначали вміст $\mathrm{H}_{2} \mathrm{~S}$, активність NADPHоксидази (КФ 1.6.3.1), супероксиддисмутази (КФ 1.15.1.1), вміст малонового діальдегіду (МДА), карбонільних груп білків (КГ). У сироватці крові оцінювали вміст гомоцистеїну, активність аспартатамінотрасферази (АСТ) та креатинфосфокінази (КФК). Статистичну обробку результатів проводили за допомогою програми SPSS Statistica 17.0.

Результати. Тривале введення тіолактону гомоцистеїну супроводжується збільшенням вмісту гомоцистеїну в сироватці крові та зменшенням рівня гідроген сульфіду в міокарді у самців відповідно на 111 та 43,3 \% (p<0,05), а у самок - на 82,4 та 25,1 \% ( $<<0,05)$, порівняно з відповідним контролем.

У самців з гіпергомоцистеїнемією зменшення активності супероксиддисмутази, а також зростання активності НАДФН-оксидази, вмісту МДА та КГ в міокарді становило відповідно 33,2; 52,7; 89,3 та 102 \%, тоді як у самок зміни вказаних показників були меншими і становили 23,7; 33,3; 68,3 та 78,6 \% відносно контролю.

За умов гіпергомоцистеїнемії у самців розвивається більш виражений цитоліз кардіоміоцитів (активність АСТ та КФК у сироватці крові зростає відповідно на 39,2 та 42,5 \% відносно контролю), ніж у самок (активність АСТ та КФК в сироватці крові зростає на 24,9 та $31,3 \%$ ).

Висновки. Встановлено, що введеннятіолактонугомоцистеїнупротягом 28 діб викликаєу самців більш істотне зменшення активності супероксиддисмутази та збільшення активності НАДФН-оксидази, процесів пероксидації ліпідів і протеїнів, ніж у самок. Поряд з цим у самців реєструється більш виразний цитоліз кардіоміоцитів, ніж у особин протилежної статі.

КлючОВІ СлОВА: гіпергомоцистеїнемія; гідроген сульфід; оксидативний стрес; міокард; стать.

Вступ. Гіпергомоцистеїнемія $\epsilon$ незалежним фактором ризику патології серця та судин [1]. Одним із механізмів кардіотоксичної дії високих концентрацій гомоцистеїну є оксидативний стрес [2]. За умов гіпергомоцистеїнемії в міокарді розвивається про-антиоксидантний дисбаланс, який асоціюється з посиленням процесів вільнорадикального окиснення ліпідів та протеїнів.

Важливу роль у розвитку серцево-судинної патології відіграє стать [3]. Показано, що поширеність ішемічної хвороби серця та артеріальної гіпертензії зростає з віком і до 55 років переважає в чоловічій популяції, а після - в жіночій [4]. Однак статеві особливості впливу гіпергомоцистеїнемії на показники про-антиоксидантної системи в міокарді залишаються невивченими. Вирішення цього питання $\epsilon$ досить актуальним, адже дозволить розкрити нові молекулярні механізми стать-асоційованих захворювань серця та судин.

Мета дослідження - оцінити показники проантиоксидантної системи в міокарді, маркери ци- толізу кардіоміоцитів у сироватці крові у самців та самок щурів за умов гіпергомоцистеїнемії.

Матеріал і методи дослідження. Досліди проведені на 40 білих лабораторних щурах обох статей масою 220-280 г. Тварини перебували в стандартних умовах з природним світловим режимом день/ніч, воду і корм отримували ad libitum. Тварин годували напівсинтетичною крохмально-казеїновою дієтою із збалансованим вмістом всіх макро- та мікронутрієнтів. Дослідження проведено за загальними етичними принципами експериментів на тваринах згідно 3 Першим Національним конгресом України з біоетики (Київ, 2001) та вимогами «Європейської конвенції про захист хребетних тварин, що використовуються для дослідних та інших наукових цілей» (Страсбург, 1986).

Модель гіпергомоцистеїнемії створювали шляхом введення тіолактону D, L-гомоцистеїну (Sigma, США) внутрішньошлунково в дозі 100 мг/ кг маси на 1 \% розчині крохмалю 1 раз на добу впродовж 28 діб [5]. Знеживлювали тварин мето- 
Огляди літератури, оригінальні дослідження, погляд на проблему

дом декапітації під пропофоловим наркозом («Fresenius Kabi» 60 мг/кг внутрішньоочеревинно).

Вміст $\mathrm{H}_{2} \mathrm{~S}$ в міокарді визначали за методикою [6]. Активність NADPH-оксидази (КФ 1.6.3.1) визначали за поглинанням NADPH при 340 нм [7], супероксиддисмутази (КФ 1.15.1.1) - за здатністю гальмувати окиснення кверцетину [8]. Вміст малонового діальдегіду (МДА) визначали за реакцією з тіобарбітуровою кислотою [9], карбонільних груп білків (КГ) - за реакцією з 2,4-динітрофенілгідразином [10]. Активність аспартатамінотрасферази (АСТ) та креатинфосфокінази (КФК) визначали з використанням наборів ТОВ Філісіт-Діагностика, Спайн Лаб (Україна). Вміст гомоцистеїну в сироватці крові визначали з використанням набоpy «Homocysteine ElA» (Axis-Shield, Англія). Статистичну обробку результатів проводили за допомогою програми SPSS Statistica 17.0. Достовірність різниці між показниками оцінювали за параметричним t-критерієм Стьюдента (при нормальному розподілі) та непараметричним U-критерієм Манна-Уїтні (при невідповідності нормальному розподілу). Для оцінки зв'язків між показниками проводили кореляційний аналіз за Пірсоном. Вірогідними вважали дані при р<0,05.

Результати й обговорення. Спершу ми оцінили вплив тіолактонової гіпергомоцистеїнемії на вміст гомоцистеїну в сироватці крові та рівень гідроген сульфіду в міокарді самців та самок щурів (табл. 1). 3'ясувалося, що введення тіолактону гомоцистеїну упродовж 28 діб викликало збіль- шення рівня гомоцистеїну в сироватці крові та зменшення вмісту гідроген сульфіду в міокарді у самців відповідно на 111 та 43,3 \% (р<0,05), а у самок - на 82,4 та 25,1\% ( $<<0,05)$, порівняно з відповідним контролем. Слід зазначити, що у самців базальний рівень гомоцистеїну в сироватці крові був вищим, а гідроген сульфіду в міокарді - нижчим, ніж у самок, і за умов гіпергомоцистеїнемії ці відмінності суттєво поглиблювались. Так, у самців з групи контролю вміст гомоцистеїну в сироватці крові був більшим, а рівень гідроген сульфіду в міокарді-меншим на 18,9 та 20,6 \% (р<0,05), ніж у самок, тоді як у самців з гіпергомоцистеїнемією на 29,9 та 59,5\% (p<0,05) відповідно.

Гіпергомоцистеїнемія ініціює розвиток дисбалансу про-антиоксидантних ензимів у міокарді щурів обох статей, який є істотно більшим у самців (табл. 2). Встановлено, що станом на 28 добу введення тіолактону гомоцистеїну активність продукції супероксидного аніона за участі НАДФН $\epsilon$ більшою, відповідно на 52,7 та 33,3 \% у самців та самок, порівняно з контролем. Поряд з цим відмічається зменшення інактивації супероксидного аніона за участі супероксиддисмутази відповідно на 33,2 та 23,7\% ( $<<0,05)$ у самців та самок щурів, порівняно з контролем. За цих умов між вмістом гомоцистеїну в крові та активністю НАДФНоксидази виникав прямий зв'язок та обернений зв'язок з активністю в міокарді супероксиддисмутази (у самців $r=0,67 ;-0,63, p<0,05$; у самок $r=0,61$; $-0,59, \mathrm{p}<0,05)$. Водночас між вмістом $\mathrm{H}_{2} \mathrm{~S}$ у міокар-

Таблиця 1. Вплив гіпергомоцистеїнемії на рівень гомоцистеїну в сироватці та вміст $\mathrm{H}_{2}$ S в міокарді щурів обох статей $(M \pm m, n=10)$

\begin{tabular}{|c|c|c|c|}
\hline Групи тварин & Стать & $\begin{array}{c}\text { Вміст гомоцистеїну в сироватці крові, } \\
\text { мкмоль/л }\end{array}$ & Вміст $\mathrm{H}_{2} \mathrm{~S}$ в міокарді, нмоль/мг протеїну \\
\hline \multirow[t]{2}{*}{ Контроль } & Самці & $7,68 \pm 0,13$ & $2,60 \pm 0,11$ \\
\hline & Самки & $6,23 \pm 0,12^{\circ}$ & $3,14 \pm 0,10^{\circ}$ \\
\hline \multirow[t]{2}{*}{ ГГЦ } & Самці & $16,2 \pm 0,52 *$ & $1,47 \pm 0,07^{*}$ \\
\hline & Самки & $11,4 \pm 0,34^{*}$ & $2,35 \pm 0,09 *^{\circ}$ \\
\hline
\end{tabular}

Примітки: 1. * - статистично достовірна відмінність $(p<0,05)$ відносно відповідної групи контролю;

$2^{\circ}{ }^{\circ}$ - статистично достовірна відмінність $(p<0,05)$ між самцями та самками в межах групи.

Таблиця 2. Вплив гіпергомоцистеїнемії на активність про- та антиоксидантних ензимів в міокарді щурів обох статей $(M \pm m, n=10)$

\begin{tabular}{|l|l|c|c|}
\hline \multirow{2}{*}{ Групи тварин } & \multicolumn{1}{|c|}{ Стать } & $\begin{array}{c}\text { НАДФН-оксидаза, нмоль/хв·мг } \\
\text { протеїну }\end{array}$ & $\begin{array}{c}\text { Супероксиддисмутаза, ум.од./мг } \\
\text { протеїна }\end{array}$ \\
\hline \multirow{2}{*}{ Контроль } & Самці & $1,23 \pm 0,07$ & $3,66 \pm 0,14$ \\
\cline { 2 - 4 } & Самки & $0,82 \pm 0,04^{\circ}$ & $4,55 \pm 0,16^{\circ}$ \\
\hline \multirow{2}{*}{ ГГЦ } & Самці & $1,88 \pm 0,09^{*}$ & $2,45 \pm 0,10^{*}$ \\
\cline { 2 - 4 } & Самки & $1,10 \pm 0,11^{\circ}$ & $3,47 \pm 0,1 *^{*^{\circ}}$ \\
\hline
\end{tabular}

Примітки: 1. * - статистично достовірна відмінність $(p<0,05)$ відносно відповідної групи контролю;

2. ${ }^{\circ}$ - статистично достовірна відмінність $(p<0,05)$ між самцями та самками в межах групи. 
Огляди літератури, оригінальні дослідження, погляд на проблему

ді та активністю в міокарді НАДФН-оксидази та супероксиддисмутази виявлялись більш сильні та протилежно спрямовані кореляції (у самців г=$0,77 ; 0,76, p<0,05 ;$ у самок $r=-0,68 ; 0,65, p<0,05)$. Гіпергомоцистеїнемія поглиблювала статевий диморфізм базальної активності досліджуваних про-антиоксидантних ензимів. Так, у групі з гіпергомоцистеїнемією у самців активність НАДФНоксидази була на 41,5 \% більшою, а активність супероксиддисмутази - на 41,7 \% меншою, ніж у самок, тоді як в групі контролю ці відмінності становили 33,0 та $24,2 \%(p<0,05)$.

За умов тіолактонової гіпергомоцистеїнемії збільшується активність процесів пероксидації ліпідів та окисної модифікації білків у міокарді щурів обох статей, однак більш виразні зміни реєструються у самців (табл. 3). Виявилось, що на тлі гіпергомоцистеїнемії відмічається вірогідне зростання вмісту в міокарді МДА (на 89,3 \% у самців проти 68,3 \% у самок, р<0,05) та КГ (на $102 \%$ у самців проти 78,6 \% у самок, р<0,05), порівняно з відповідним контролем. Рівень МДА та КГ в серці виявляє прямий зв'язок з рівнем гомоцистеїну в крові (у самців $г=0,65-0,69 ;$ у самок $r=0,60-0,62$; $\mathrm{p}<0,05)$ та обернений зв'язок з вмістом гідроген сульфіду в міокарді (у самців г=-0,72; -0,76, p<0,05; у самок $r=-0,66 ;-0,68, p<0,05)$. За умов гіпергомоцистеїнемії статеві відмінності активності процесів пероксидації ліпідів та протеїнів у міокарді $\epsilon$ більш виразними: у контрольній групі у самців вміст МДА та КГ є вірогідно більшим на 26,5-
$27,4 \%$ ( $><0,05)$, ніж у самок; на тлі гіпергомоцистеїнемії ці відмінності $\epsilon$ більш суттєвими і становлять $34,9-35,4 \%(p<0,05)$.

Гіпергомоцистеїнемія спричиняє розвиток цитолізу кардіоміоцитів у тварин обох статей, але виразність вказаних змін більша у самців (табл. 4). Показано, що за умов тривалого введення тіолактону гомоцистеїну відмічається вірогідне зростання в крові активності АСТ (на 39,2 \% у самців проти 24,9 \% у самок, р<0,05) та КФК (на 42,5 \% у самців проти 31,3 \% у самок, $р<0,05)$, порівняно 3 відповідним контролем. За цих умов між активністю АСТ і КФК та вмістом гомоцистеїну в крові виникають прямі зв'язки (у самців $r=0,66-0,69 ;$ у самок $r=0,59-0,64 ; p<0,05)$, тоді як з вмістом гідроген сульфіду в міокарді - обернені зв'язки (у самців г=-0,79; -0,76, $p<0,05$; у самок $r=-0,65 ;-0,66$, $\mathrm{p}<0,05)$. Виявляється, що в контрольній групі тварин відсутні статистично достовірні відмінності активності АСТ та КФК між самцями та самками щурів і з'являються вони за умов гіпергомоцистеїнемії - у самців активність вказаних ензимів на $12,4-12,7$ \% більша $(p<0,05)$, ніж у самок.

Проведені дослідження засвідчили, що введення тіолактону гомоцистеїну впродовж 28 діб викликає зростання рівня гомоцистеїну в крові та зменшення вмісту гідроген сульфіду в міокарді, що асоціюється з розвитком дисбалансу проантиоксидантних систем в серці, зростанням активності процесів пероксидації ліпідів і протеїнів та розвитком цитолізу кардіоміоцитів у самців та

Таблиця 3. Вплив гіпергомоцистеїнемії на вміст продуктів пероксидації ліпідів та протеїнів в міокарді щурів обох статей $(M \pm m, n=10)$

\begin{tabular}{|c|c|c|c|}
\hline Групи тварин & Стать & $\begin{array}{c}\text { МДА, } \\
\text { мкмоль/г тканини }\end{array}$ & $\begin{array}{c}\text { КГ, } \\
\text { нмоль/мг протеїну }\end{array}$ \\
\hline \multirow[t]{2}{*}{ Контроль } & Самці & $10,0 \pm 0,35$ & $0,95 \pm 0,04$ \\
\hline & Самки & $7,25 \pm 0,27^{\circ}$ & $0,70 \pm 0,03^{\circ}$ \\
\hline \multirow[t]{2}{*}{ ГГЦ } & Самці & $18,9 \pm 0,27 *$ & $1,92 \pm 0,09 *$ \\
\hline & Самки & $12,2 \pm 0,24^{*^{\circ}}$ & $1,25 \pm 0,12^{* \circ}$ \\
\hline
\end{tabular}

Примітки: 1. * - статистично достовірна відмінність $(p<0,05)$ відносно відповідної групи контролю;

$2 .^{\circ}$ - статистично достовірна відмінність $(p<0,05)$ між самцями та самками в межах групи.

Таблиця 4. Вплив гіпергомоцистеїнемії на активність маркерних ферментів цитолізу кардіоміоцитів в сироватці крові щурів обох статей $(M \pm m, n=10)$

\begin{tabular}{|l|l|c|c|}
\hline \multicolumn{1}{|c|}{ Групи тварин } & \multicolumn{1}{|c|}{ Стать } & $\begin{array}{c}\text { АСТ, } \\
\text { мкмоль/хв·л }\end{array}$ & $\begin{array}{c}\text { КФК, } \\
\text { Од./л }\end{array}$ \\
\hline \multirow{2}{*}{ Контроль } & Самці & $37,0 \pm 0,90$ & $77,2 \pm 4,26$ \\
\cline { 2 - 4 } & Самки & $36,1 \pm 0,71$ & $73,1 \pm 3,65$ \\
\hline \multirow{2}{*}{ ГГЦ } & Самці & $51,5 \pm 0,96 *$ & $110 \pm 3,67 *$ \\
\cline { 2 - 4 } & Самки & $45,1 \pm 0,65^{*}$ & $96,0 \pm 3,83^{*}$ \\
\hline
\end{tabular}

Примітки: 1. * - статистично достовірна відмінність $(p<0,05)$ відносно відповідної групи контролю;

$2 .^{\circ}$ - статистично достовірна відмінність $(p<0,05)$ між самцями та самками в межах групи. 
Огляди літератури, оригінальні дослідження, погляд на проблему

самок щурів. Зауважимо, що всі вказані біохімічні порушення були більш виразними у самців.

Виникає питання щодо причин, які обумовлюють статеві відмінності перебігу вільнорадикальних процесів у міокарді щурів за умов гіпергомоцистеїнемії. Як відомо, високі рівні гомоцистеїну та низький вміст гідроген сульфіду $\epsilon$ важливими чинниками, що ініціюють розвиток оксидативного стресу $[2,11]$. Нами показано, що тривале введення тіолактону гомоцистеїну викликає стать-специфічні зміни рівня цих метаболітів: у самців відмічається більш виразне зростання рівня гомоцистеїну в сироватці крові та зменшення вмісту гідроген сульфіду в міокарді, ніж у самок. Результати кореляційного аналізу показали існування зв'язків між рівнями гомоцистеїну, гідроген сульфіду та показниками оксидативного стресу в міокарді самців та самок щурів за умов гіпергомоцистеїнемії. Очевидно, статеві відмінності концентрації гомоцистеїну в крові та гідроген сульфіду в міокарді можуть бути однією із причин різної активності процесів вільнорадикального окиснення ліпідів та протеїнів у самців та самок на тлі гіпергомоцистеїнемії.

Нами виявлено, що у особин чоловічої статі базальна продукція реакційноздатних форм кисню та активність процесів пероксидації ліпідів та протеїнів у міокарді $\epsilon$ вірогідно вищими, ніж у самок. Отримані нами результати узгоджуються із літературними даними $[12,13]$, в яких показано, що у сироватці крові у жінок пременопаузального віку активність прооксидантного ензиму НАДФН- оксидази $\epsilon$ вищою, тоді як активність антиоксидантного ензиму супероксиддисмутази - меншою, порівняно з чоловіками того ж віку. Тому можна припустити, що різна вихідна активність цих процесів у міокарді самців та самок щурів $\epsilon$ підґрунтям, на якому поглиблюються статеві відмінності вільнорадикального окиснення в серці за умов гіпергомоцистеїнемії.

Висновки. 1. Тривале введення тіолактону гомоцистеїну супроводжується збільшенням вмісту гомоцистеїну в сироватці крові та зменшенням рівня гідроген сульфіду в міокарді у самців відповідно на 111 та $43,3 \%(p<0,05)$, а у самок - на 82,4 та $25,1 \%$ $(p<0,05)$, порівняно з відповідним контролем.

2. У самців з гіпергомоцистеїнемією зменшення активності супероксиддисмутази, а також зростання активності НАДФН-оксидази, вмісту МДА та КГ в міокарді становило відповідно 33,2; 52,$7 ; 89,3$ та $102 \%$, тоді як у самок зміни вказаних показників були меншими - 23,7; 33,3; 68,3 та 78,6 \% відносно контролю.

3. За умов гіпергомоцистеїнемії у самців розвивається більш виражений цитоліз кардіоміоцитів (активність АСТ та КФК в сироватці крові зростає відповідно на 39,2 та 42,5 \% відносно контролю), ніж у самок (активність АСТ та КФК у сироватці крові зростає на 24,9 та 31,3\%).

Перспективи подальших досліджень. Дослідження в цьому напрямку дозволить ідентифікувати нові молекулярні мішені, впливаючи на які можна домогтися ефективної кардіопротекції у чоловіків та жінок за умов стать-асоційованої патології серця та судин.

\section{ЛІТЕРАТУРА}

1. Loscalzo J. Epigenetic modifications: basic mechanisms and role in cardiovascular disease / J. Loscalzo, D. E. Handy // Pulm. Circ. - 2014. - Vol. 4, № 2. - P. 169-174.

2. Lai W. K. Homocysteine-Induced Endothelial Dysfunction / W. K. Lai, M. Y. Kan // Ann. Nutr. Metab. 2015. - Vol. 67, № 1. - P. 1-12.

3. Барна О. М. Гендерна кардіологія. Проекція на аритмії у жінок / О. М. Барна // Медицинские аспекты здоровья женщины. - 2007. - Т. 4, № 7. - С. 14-18.

4. Sex and gender differences in myocardial hypertrophy and heart failure / V. Regitz-Zagrosek, S. Oertelt-Prigione, U. Seeland [et al.] // Circ. J. - 2010. Vol. 74 (7). - P. 1265-1273.

5. Homocysteine thiolactone-induced hyperhomocysteinemia does not alter concentrations of cholesterol and SREBP-2 target gene mRNAS in rats / G. I. Stangl, K. Weisse, C. Dinger [et al.] // Exp. Biol. Med. (Maywood). 2007. - Vol. 232, № 1. - P. 81-87.

6. Carvedilol induces endogenous hydrogen sulfide tissue concentration changes in various mouse organs / B. Wiliński, J. Wiliński, E. Somogyi [et al.] // Folia Biol
(Krakow). - 2011. - Vol. 59, № 3-4. - P. 151-155.

7. p22phox mRNA expression and NADPH oxidase activity are increased in aortas from hypertensive rats / T. Fukui, N. Ishizaka, S. Rajagopalan [et al.] // Circ. Res. 1997. - Vol. 80, № 1. - P. 45-51.

8. Костюк В. А. Простой и чувствительный метод определения активности супероксиддисмутазы, основанный на реакции окисления кверцетина / В. А. Костюк, А. И. Потапович, Ж. В. Ковалева // Вопр. мед. химии. - 1990. - Т. 36, № 2. - С. 88-91.

9. Владимиров Ю. В. Перекисное окисление липидов в биологических мембранах / Ю. В. Владимиров, А. И. Арчаков. - М. : Наука, 1972. - 252 с.

10. Заічко Н. В. Окислювальна модифікація білків сироватки крові як маркер активності ревматоїдного артриту та її зміни під впливом фармакотерапії амізоном, індометацином, німесулідом / Н. В. Заічко // Вісник Вінницького державного медичного університету. - 2003. - № 7, (2/2). - С. $664-666$.

11. Kimura Y. Hydrogen sulphide increases glutathione production and suppresses oxidative stress in mitochondria 
Огляди літератури, оригінальні дослідження, погляд на проблему

/ Y. Kimura, Y. I. Goto, H. Kimura // Antioxidants and Redox Signaling. - 2010. - Vol. 12, № 1. - P. 1-13.

12. Effect of gender and sex hormones on vascular oxidative stress / A. A. Miller, T. M. De Silva, K. A. Jackman, C. G. Sobey // Clin. Exp. Pharmacol. Physiol. - 2007. -
Vol. 34, № 10. - P. 1037-1043.

13. Sex hormones modulate circulating antioxidant enzymes: impact of estrogen therapy / F. Bellanti, M. Matteo, T. Rollo [et al.] // Redox. Biol. - 2013. - Vol. 19, № 1. - P. 340-346.

\section{REFERENCES}

1. Loscalzo, J., \& Handy, D.E. (2014). Epigenetic modifications: basic mechanisms and role in cardiovascular disease. Pulm. Circ. 4 (2), 169-174.

2. Lai, W.K., \& Kan, M.Y. (2015). Homocysteineinduced endothelial dysfunction. Ann. Nutr. Metab. 67 (1), $1-12$.

3. Barna, O.M. (2007). Henderna kardiolohiia. Proektsiia na arytmii u zhinok [Gender cardiology. Projection on arrhythmias in women]. Meditsinskie aspekty zdorovia Zhenshchiny - Medical Aspects of Women's Health, 4 (7), 14-18 [in Ukrainian].

4. Regitz-Zagrosek, V., Oertelt-Prigione, S. \& Seeland U. (2010). Sex and gender differences in myocardial hypertrophy and heart failure. Circ. J., 74 (7), 1265-1273.

5. Stangl, G.I., Weisse, K., \& Dinger, C. (2007). Homocysteine thiolactone-induced hyperhomocysteinemia does not alter concentrations of cholesterol and SREBP-2 target gene mRNAS in rats. Exp. Biol. Med. (Maywood), 232, (1), 81-87.

6. Wiliński, B., Wiliński, J., \& Somogyi, E. (2011). Carvedilol induces endogenous hydrogen sulfide tissue concentration changes in various mouse organs. Folia Biol. (Krakow), 59 (3-4), 151-155.

7. Fukui, T., Ishizaka, N., \& Rajagopalan, S. (1997). p22phox mRNA expression and NADPH oxidase activity are increased in aortas from hypertensive rats. Circ. Res., 80, 45-51.

8. Kostiuk, V.A., Potapovich, A.I., \& Kovaleva, Zh.V. (1990). Prostoi i chuvstvitelnyi metod opredeleniia aktivnosti superoksiddismutazy, osnovannyi na reaktsii okisleniia kvertsetina [A simple, sensitive assay for determination of superoxide dismutase activity based on reaction of quercetin oxidation]. Vopr. med. khimii Problems of Medical Chemistry, 36 (2), 88-91 [in Russian].

9. Vladimirov lu.V. \& Archakov A.I. (1972). Perekisnoe okislenie lipidov $v$ biologicheskikh membranakh [Lipid peroxidation in biological membranes]. Moscow: Nauka [in Russian].

10. Zaichko N.V. (2003). Okysliuvalna modyfikatsiia bilkiv syrovatky krovi yak marker aktyvnosti revmatoidnoho artrytu ta ii zminy pid vplyvom farmakoterapii amizonom, indometatsynom, nimesulidom [Oxidative modification of serum proteins as a marker of rheumatoid arthritis activity and its changes under the influence of pharmacotherapy amizon, indomethacin, nimesulide]. Visnyk Vinnytskoho derzhavnoho medychnoho universytetu - Journal of Vinnytsia State Medical University, 7 (2), 664-666 [in Ukrainian].

11. Kimura, Y., Goto, Y.I., Kimura, H. (2010). Hydrogen sulphide increases glutathione production and suppresses oxidative stress in mitochondria. Antioxidants and Redox Signaling, 12 (1), 1-13.

12. Miller, A.A., De Silva, T.M., Jackman, K.A., \& Sobey C.G. (2007). Effect of gender and sex hormones on vascular oxidative stress. Clin. Exp. Pharmacol. Physiol., 34 (10), 1037-1043.

13. Bellanti, F., Matteo, M., \& Rollo T. (2013). Sex hormones modulate circulating antioxidant enzymes: impact of estrogen therapy. Redox. Biol., 19 (1), 340-346.

\title{
ПОЛОВЫЕ РАЗЛИЧИЯ ПОКАЗАТЕЛЕЙ ПРО-АНТИОКСИДАНТНОЙ СИСТЕМЫ В МИОКАРДЕ КРЫС В УСЛОВИЯХ ГИПЕРГОМОЦИСТЕИНЕМИИ
}

๑А. В. Мельник

\author{
Винницкий национальный медицинский университет имени Н. И. Пирогова, г. Винница, Украина
}

РЕЗЮМЕ. Гипергомоцистеинемия является независимым фактором риска патологии сердца и сосудов. Одним из механизмов кардиотоксического действия высоких концентраций гомоцистеина является оксидативный стресс. В условиях гипергомоцистеинемии в миокарде развивается про-антиоксидантный дисбаланс, который ассоциируется с усилением процессов свободнорадикального окисления липидов и протеинов. Однако половые особенности влияния гипергомоцистеинемии на показатели про-антиоксидантной системы в миокарде остаются неизученными.

Цель исследования - оценить влияние гипергомоцистеинемии на показатели оксидативного стресса в миокарде и маркеры цитолиза кардиомиоцитов у самцов и самок крыс.

Материалы и методы. Опыты проведены на 40 белых лабораторных крысах обоего пола массой 220280 г. Модель гипергомоцистеинемии создавали путем введения тиолактона D, L-гомоцистеина (Sigma, CШA) внутрижелудочно в дозе 100 мг/кг массы в течение 28 суток. В миокарде определяли содержание $\mathrm{H}_{2} \mathrm{~S}$, активность 
Огляди літератури, оригінальні дослідження, погляд на проблему

NADPH-оксидазы (КФ 1.6.3.1), супероксиддисмутазы (КФ 1.15.1.1), содержание малонового диальдегида (МДА), карбонильных групп белков (КГ). В сыворотке крови оценивали содержание гомоцистеина, активность аспартатаминотрасферазы (АСТ) и КФК (КФК). Статистическую обработку результатов проводили с помощью программы SPSS Statistica 17.0.

Результаты. Длительное введение тиолактона гомоцистеина сопровождается увеличением содержания гомоцистеина в сыворотке крови и уменьшением уровня гидроген сульфида в миокарде у самцов соответственно на 111 и 43,3 \% (p<0,05), а у самок - на 82,4 и 25,1 \% ( $<<0,05)$, по сравнению с соответствующим контролем.

У самцов с гипергомоцистеинемией уменьшение активности супероксиддисмутазы, а также повышение активности НАДФН-оксидазы, содержания МДА и КГ в миокарде составило соответственно 33,$2 ; 52,7 ; 89,3$ и 102 \%, тогда как у самок изменения указанных показателей были меньше и составляли 23,7; 33,3; 68,3 и 78,6 \% относительно контроля.

В условиях гипергомоцистеинемии у самцов развивается более выраженный цитолиз кардиомиоцитов (активность АСТ и КФК в сыворотке крови возрастает соответственно на 39,2 и 42,5 \% относительно контроля), чем у самок (активность АСТ и КФК в сыворотке крови возрастает на 24,9 и 31,3 \%).

Выводы. Установлено, что введение тиолактона гомоцистеина в течение 28 суток вызывает у самцов более существенное уменьшение активности супероксиддисмутазы и увеличение активности НАДФН-оксидазы, процессов перекисного окисления липидов и протеинов, чем у самок. Наряду с этим у самцов регистрируется более выраженный цитолиз кардиомиоцитов, чем у особей противоположного пола.

Ключевые слова: гипергомоцистеинемия; гидроген сульфид; оксидативный стресс; миокард; пол.

\section{SEX DIFFERENCES IN PRO-ANTIOXIDANT SYSTEM INDICATORS IN MYOCARDIUM OF RATS UNDER THE CONDITIONS OF HYPERHOMOCYSTEINEMIA}

\section{Pyrohov Vinnytsia National Medical University}

๑A. V. Melnik

SUMMARY. Hyperhomocysteinemia is an independent risk factor of heart and blood vessels pathologies. One of the mechanisms of cardiotoxic action of homocysteine high concentrations is oxidative stress. In conditions of hyperhomocysteinemia in myocardium develops pro-antioxidant imbalance which is associated with exaggeration of the processes of free radical oxidation of lipids and proteins. However, sexual characteristics of hyperhomocysteinemia influence on the indicators of pro-antioxidant system in myocardium remain unknown.

The aim of the study is to evaluate the influence of hyperhomocysteinemia on indicators of oxidative stress in myocardium and the markers of cardiomyocytes cytolysis in males and female rats.

Materials and Methods. The experiments were performed on 40 white laboratory rats of both sexes weighing 220-280 g. The model of hyperhomocysteinemia was created by introducing of touchtone D, L-homocysteine (Sigma, USA) intraperitoneally at the dose of $100 \mathrm{mg} / \mathrm{kg}$ during 28 days. In myocardium, content of $\mathrm{H}_{2} \mathrm{~S}, \mathrm{NADPH}$-oxidase activity, superoxide dismutase, content of malondialdehyde (MDA), protein carbonyl groups (CG) was determined. In blood serum, content of homocysteine, aspartate aminotransferase activity (AST) and creatine phosphokinase (CPK) was evaluated. Statistical processing of the results was performed using the program Statistica SPSS 17.0.

Results and Discussion. Prolonged introduction to thiolactone homocysteine is accompanied by the increase of homocysteine in blood serum and reduce of hydrogen sulfide level in myocardium in males, respectively by 111 and $43.3 \%(p<0.05)$, while in females - by 82.4 and $25.1 \%(p<0.05)$, compared with the corresponding control group.

In males with hyperhomocysteinemia decrease in superoxide dismutase activity and increase of NADPH-oxidase activity, content of MDA and CG in myocardium were respectively $33.2 ; 52.7 ; 89.3$ and $102 \%$, whereas in females the changes of these indicators were less and amounted to $23.7 ; 33.3 ; 68.3$ and $78.6 \%$, relative to the control group.

In conditions of hyperhomocysteinemia, males develop more pronounced cytolysis of cardiomyocytes (activity of AST and CPK in serum increases, respectively, by 39.2 and $42.5 \%$, relative to the control group) than in females (levels of AST and CPK in serum increases by 24.9 and $31.3 \%$ ).

Conclusions. It is established that introduction of thiolactone homocysteine during 28 days causes in males a more significant decrease in superoxide dismutase activity and increased activity of NADPH-oxidase, processes of lipids and proteins peroxidation than in females. Along with this, the males recorded more pronounced cytolysis of cardiomyocytes than individuals of the opposite sex.

KEY WORDS: hyperhomocysteinemia; hydrogen sulfide; oxidative stress; myocardium; sex. 